\title{
POLA PERILAKU PENELUSURAN INFORMASI MAHASISWA DI ERA DIGITAL NATIVE
}

\author{
Atiqa Nur Latifa Hanum \\ Prodi D3 Perpustakaan FKIP Universitas Tanjungpura, Pontianak - Indonesia \\ e-mail: atiqanurlatifa@ymail.com
}

\begin{abstract}
Human behavior in searching different information but can establish a pattern that can be known the model search. In the case of this study, the focus is the behavior of students in searching information to meet the learning needs on campus. Exploratory research methodology with a quantitative approach. Collecting data through distributing questionnaires to 93 respondents to the survey technique as the primary data and conducting interviews as secondary data. Data analysis techniques performed by regression analysis model tiered or SEM (structural equation modeling) with Partial Least Square approach using tools SmartPls 2.0 and SPSS program to test for normality of data. The results showed that the characteristics of all respondents belonging to the Internet generation (net generation) or better known as a digital native with instant information search behavior patterns and digital in meeting information needs. Amounting to $68.82 \%$ of respondents chose the resources in the form of electronic media format as a medium of learning than the printed media. Amounting to $62.37 \%$ of respondents prefer to access information to support their learning tasks derived from internet and as much as $54.84 \%$ using the smartphone as a support tool accessing such information. In conclusion digital native generation tend to like information search patterns that come into contact with technology, is fast and easy, and like source of information in electronic media. Thus forming the pattern of searches ranging from needs information analysis (task/add insight) - environment (economic) - access location (internet/library) - selection (source of relevant information).
\end{abstract}

Keywords: behavior, information retrieval, digital native

\section{PENDAHULUAN}

Informasi merupakan suatu komoditas yang bernilai guna positif bagi mereka yang membutuhkan. Meskipun tidak semua informasi dapat dikatakan terpercaya dan memiliki kualitas nilai informasi yang baik (valid). Berbagai pandangan mengenai informasi sebenarnya tergantung dari sudut pandang orang yang memaknai. Namun yang paling penting bahwa informasi berguna bagi setiap orang untuk meningkatkan kualitas kehidupannya.

Tidak ada seorang pun di dunia ini yang tidak membutuhkan informasi. Terlebih lagi jika informasi dikaitkan untuk pengembangan diri. Menurut Katz, Gurevitch, dan Haas (dalam Yusup dan Subekti, 2010:91), kebutuhan informasi seseorang dipicu oleh 5 yakni kebutuhan kognitif, kebutuhan afektif, kebutuhan integrasi personal, kebutuhan integrasi sosial, dan kebutuhan berkhayal. Guna memenuhi kebutuhan informasi tersebut, seseorang akan melakukan penelusuran informasi dari berbagai sumber yang dipengaruhi oleh interaksi sosial maupun interaksi dengan sistem informasi.

Sepanjang hidupnya, manusia akan terus membutuhkan informasi untuk menjalani kehidupannya sehari-hari. Tidak terkecuali mahasiswa. Sebagai sumber daya manusia (SDM) yang potensial untuk membangun bangsa dan mensejahterakan lingkungan sekitarnya, Mahasiswa adalah salah satu generasi pembelajar yang memiliki kewajiban untuk belajar. Dalam upayanya untuk belajar, maka seorang mahasiswa 
membutuhkan sumber informasi untuk mengisi kebutuhan informasinya.

Masing-masing mahasiswa memiliki kebiasaan yang membentuk pola perilakunya dalam melakukan penelusuran informasi. Faktanya, tidak semua mahasiswa memiliki kompetensi dan kemampuan dalam melakukan penelusuran informasi bahkan sekalipun mereka telah terbiasa menelusur informasi dengan sarana dan prasarana pendukung yang tersedia di lingkungan sekitarnya. Kemampuan seseorang dalam melakukan penelusuran akan memengaruhi sumber informasi yang ia gunakan untuk mencapai tujuan tertentu dalam hidupnya.

Motivasi diartikan sebagai sebuah dorongan atau hal yang menjadi penyebab mengapa seseorang melakukan sesuatu. Dengan kata lain motivasi sebagai alasan seseorang untuk melakukan sesuatu. Ada unsur kesengajaan yang mendorongnya. Sejauh ini sudah banyak teori motivasi yang dikenal seperti teori kebutuhan hierarki Abraham Maslow, teori ERG Alderfer, teori kebutuhan belajar McCllelland, dan teori dua faktor Herzberg.

Dari sekian banyak teori motivasi tersebut, ditinjau dari kedekatannya dengan penelitian ini dan mahasiswa sebagai sasaran objek penelitian maka teori dari McCllelland mengenai kebutuhan belajar sangat tepat bila disandingkan dengan pengembangan diri mahasiswa dalam upayanya melakukan penelusuran informasi. Teori kebutuhan ini memengaruhi perilaku seseorang dan menghubungkannya dengan belajar karena ada dorongan yang kuat untuk berhasil.

Menurut Mendoza, teori tersebut mengemukakan tiga karakteristik: 1) Need for Achievement. Artinya dorongan yang akan mengarahkan seseorang untuk berjuang lebih keras dalam memperoleh pencapaian pribadi hingga mendapati penghargaan; 2) Need for Power. Artinya seseorang berkeinginan memiliki pengaruh atau bahkan menjadi yang berpengaruh dan dapat mengendalikan individu lain; dan 3) Need for Affiliation. Artinya dorongan seseorang dalam kebutuhan untuk memperoleh hubungan sosial yang baik dalam lingkungan kerja dan cenderung lebih menyukai siatuasi kooperatif dibandingkan kompetitif.
Kebutuhan informasi merupakan kebutuhan sekunder manusia sebagai akibat timbulnya kesadaran tentang kurangnya pemahaman akan makna dari suatu kebutuhan dasarnya (primer). Ini merupakan situasi yang terjadi dalam diri manusia yang dirasakan tidak memadai oleh manusia yang bersangkutan untuk mencapai tujuan tertentu dalam hidupnya. Jadi kebutuhan informasi dapat dikategorikan sebagai kebutuhan sekunder seseorang yang muncul karena dipicu oleh motivasi. Kebutuhan informasi seseorang beraneka ragam, dari yang sederhana hingga yang kompleks.

Dalam memenuhi kebutuhan informasinya, seseorang akan menentukan di mana ia akan mencari sumber yang dianggap mampu menjawab persoalan yang sedang ia cari. Sumber informasi dapat diperoleh dalam bentuk dokumen maupun nondokumen. Sumber informasi dalam bentuk dokumen meliputi buku, jurnal, prosiding, majalah, surat kabar, kamus, dan lain sebagainya. Sedangkan sumber informasi dalam bentuk nondokumen seperti manusia dan organisasi (lembaga). Jadi, untuk mendapatkan sumber informasi yang tepat, seseorang harus mampu mengenali/ menyadari kebutuhan informasinya terlebih dahulu untuk kemudian menentukan lokasi akses informasinya sehingga mendapatkan sumber informasi yang tepat untuk memenuhi kebutuhan informasinya tersebut.

Perilaku informasi telah dipelajari sejak tahun 1950-an namun hingga saat ini masih sangat menarik untuk diteliti. Telah banyak para pakar dibidang informasi yang mempelajari mengenai perilaku informasi ini, pertama kali oleh T.D. Wilson tahun 1981, James Krikelas tahun 1983, David Ellis tahun 1987, dan Carol C. Kuhlthau tahun 1993. Diantara pakar tersebut, teori Wilson memberikan kefleksibelan untuk diteliti secara umum mengenai perilaku informasi seseorang. Artinya, seseorang yang memiliki latar belakang atau ketertarikan di bidang sosial, alamiah, maupun humaniora akan dapat dicermati perilaku informasinya melalui pendekatan teori ini. Secara singkat, teori ini memperlihatkan hubungan diantara proposisi teoritis dan proses yang menjelaskan tentang penjelasan dan pemuasan kebutuhan informasi seseorang. 
Wilson (dalam Yusup dan Subekti, 2010:104) menjelaskan bahwa perilaku penelusuran informasi bertujuan untuk mencari informasi yang dibutuhkan. Jika ditinjau dari tujuan seperti yang diungkapkan Wilson, itu artinya seseorang akan mencari informasi berdasarkan karena kebutuhan dengan tujuan tertentu atau ada hasil yang diharapkan dari pencarian tersebut. Di sini terlihat jelas bahwa ada dorongan seseorang yang menjadi alasan mengapa ia melakukan penelusuran informasi.

Dalam pencarian informasinya, seseorang akan berinteraksi baik menggunakan sistem pencarian manual melalui media tekstual seperti buku, surat kabar, majalah ilmiah, perpustakaan ataupun menggunakan media berbasis komputer seperti internet. Namun dapat juga seseorang melakukan penelusuran informasi ke individu atau lembaga yang dianggap memiliki kredibilitas untuk menjawab kebutuhan informasi seseorang.

Dalam teorinya, ada dua dimensi yang dapat menjadi variabel dalam mengukur perilaku penelusuran informasi seseorang, diantaranya: 1) Recognition of some need. Dalam melakukan penelusuran informasi, seseorang harus mengenali atau menyadari apa yang menjadi kebutuhannya sehingga penelusurannya untuk mendapatkan informasi jadi terarah. Jika penelusurannya berhasil, maka informasi yang didapatkan akan selanjutnya dipergunakan. Indikator yang digunakan dalam dimensi ini dapat dipengaruhi oleh lingkungan (internal \& eksternal) maupun motivasi.2) Searching for suchinformation. Dalam melakukan penelusuran informasi, seseorang akan dihadapkan oleh berbagai pilihan alternatif, misalnya media yang tepat untuk menemukan jawaban atas kebutuhan informasinya. Sehingga dalam dimensi ini, ada indikator sistem informasi manual, sistem informasi berbasis komputer, serta perubahan informasi yang akan mengarahkan seseorang menelusur informasi kepada "orang" yang dianggap memiliki kapabilitas terhadap bidang tersebut. Ada dua indikator, pertama penggunaan informasi. Seseorang berhenti melakukan perilaku informasi hanya pada sampai penggunaan informasi yang memperlihatkan kepuasan atau tidak puas terhadap hasil informasi yang telah ditemukan. Kedua, transfer informasi.
Setelah seseorang menggunakan informasi yang didapatkan, perilaku informasi masih terus berlanjut hingga pada tahapan transfer informasi atau meneruskan informasi tersebut kepada orang lain (diseminasi).

\section{METODOLOGI}

Penelitian ini menggunakan pendekatan kuantitatif dengan teknik survei eksplanatori yang berusaha untuk melihat kecenderungan, sikap, atau opini dari suatu populasi tertentu dengan meneliti satu sampel dari populasi tersebut. Dalam penelitian ini, sampel yang digunakan berjumlah 100 orang.

Teknik pengambilan sampel dalam penelitian ini secara random sampling. Data dinyatakan valid jika mempunyai faktor loading $\geq 0,5$ (very significant). Sedangkan pada validitas deskriminan, dapat diukur dengan skor AVE harus $>0,5$, communality $>0,5$, dan redundancy mendekati 1 . Selanjutnya untuk uji realibilitas dalam SEM dapat dilihat dari nilai composite realibility harus $>0,7$.

\section{HASIL PENELITIAN DAN PEMBAHASAN}

Tidak ada seorang pun di dunia ini yang tidak membutuhkan informasi. Bahkan bisa dikatakan bahwa siapa yang menguasai informasi maka ia menguasai dunia. Itu artinya betapa informasi memiliki kekuatan dalam memengaruhi suatu pencapaian tujuan hidup seseorang. Mulai dari anak-anak hingga orang dewasa pasti membutuhkan informasi. Hanya saja tidak semua informasi bernilai guna positif sehingga seseorang perlu memiliki wawasan mengenai literasi informasi.

Bagi mahasiswa, informasi digunakan untuk mendukung mereka dalam proses belajar di kampus. Salah satu fasilitas dari kampus yang disediakan untuk kelancaran belajar mahasiswa yakni dengan disediakannya perpustakaan perguruan tinggi bahkan didukung pula dengan ketersediaan ruang baca di masing-masing fakultas. Dengan maksud dan tujuan mahasiswa dapat mendayagunakan sumber-sumber informasi yang relevan dan ilmiah sesuai dengan kurikulum pembelajaran di kampus. 
Pada masa sekarang, gaya belajar dan menikmati bacaan berbeda dengan masa beberapa tahun ke belakang. Hal tersebut mulai terasa saat kehadiran internet mampu memengaruhi kehidupan manusia dan gaya hidupnya, termasuk dengan gaya belajarnya. Berkaitan dengan gaya belajar, mahasiswayangmenjadi responden dalampenelitian ini jika ditinjau dari generasinya, didominasi oleh para generasi Z. Generasi Z lebih dikenal dengan istilah generasi internet (net-generation), yang terlahir dari generasi $\mathrm{X}$ dan $\mathrm{Y}$ generasi $\mathrm{Z}$ (lahir tahun 1995-2010). Generasi internet tumbuh dan dibesarkan di era digital atau serba teknologi yang memiliki kecenderungan fasih terhadap teknologi, bersosial, multitasking, dan menyukai aktivitas yang berhubungan dengan dunia maya.

Itu artinya generasi $\mathrm{Z}$ sangat familiar dan bersahabat dengan internet. Maka tidak mengherankan jika kehadiran internet disambut baik bagi para mahasiswa terutama bagi mereka yang membutuhkan informasi. Fenomena gadget, teknologi informasi, kecepatan akses, dan kemudahan akses mendorong lahirnya sumber informasi dalam bentuk digital seperti buku elektronik, majalah elektronik, surat kabar elektronik, jurnal elektronik, kamus elektronik, dan lain sebagainya.

Sumber informasi tersebut dapat dengan mudah didapatkan dari internet, mulai dari yang tidak berbayar hingga yang berbayar, per bagian hingga bagian penuh, dari yang dapat diunduh hingga yang hanya dapat dibaca di platform, maupun ada pihak penyedia informasi yang menyediakan akses terbuka dan tertutup serta membuat sistem single sign on untuk pemustaka yang mengakses koleksi elektronik tersebut. Ketersediaan sumber informasi di internet menawarkan banyak pilihan baik dari segi format dokumen maupun bahasa. Kelebihannya lagi, sumber-sumber informasi tersebut dapat diakses di mana saja dan kapan saja selama orang tersebut memiliki koneksi internet. Hampir sebagian besar mahasiswa melakukan pengaksesan informasi dikarenakan motivasi mereka dalam mengerjakan tugas belajar yakni sebanyak $40,86 \%$.

Hal tersebut menunjukkan bahwa pemicu mereka dalam menelusur informasi masih dikarenakan kebutuhan mendesak dalam upaya menyelesaikan tugas yang dibebankan kepada mereka saat proses belajar.

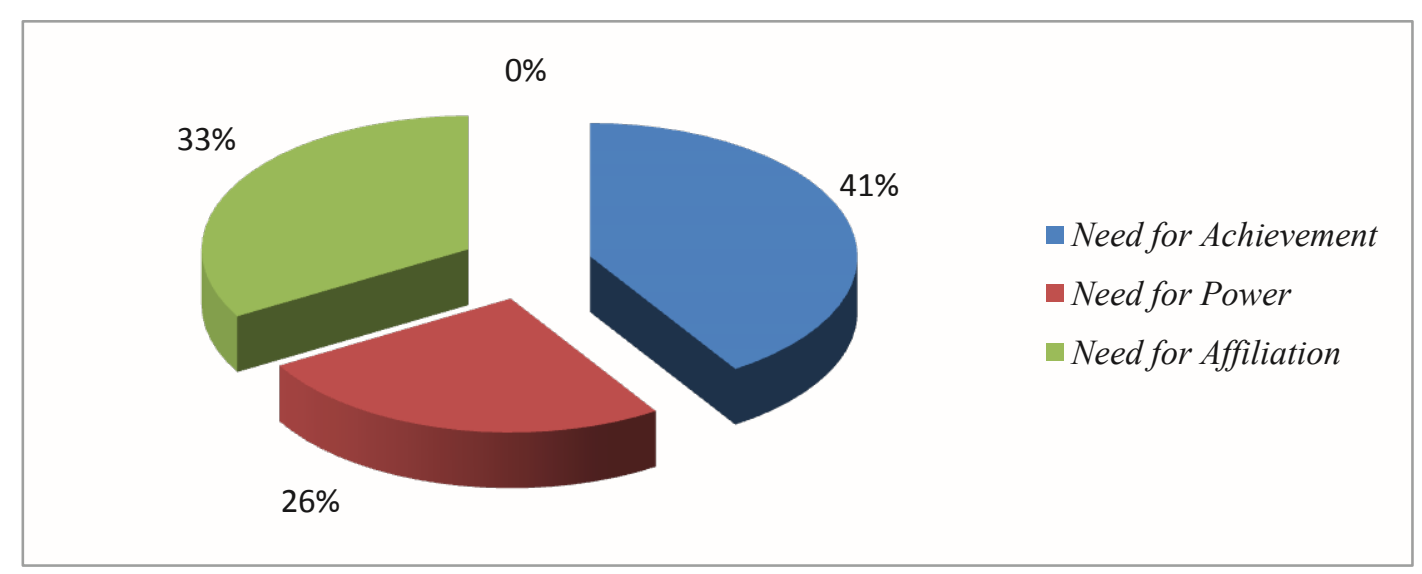

Diagram 1. Kesadaran Kebutuhan Informasi

\section{Sumber : Olah Data Primer 2016}

Dalam upaya melakukan pencarian atas kebutuhan informasi tersebut, terlebih dahulu mahasiswa akan menentukan lokasi akses yang tepat menurut mereka dalam menemukan informasi yang dibutuhkannya.

Hasil penelitian menunjukkan adanya kecenderungan mahasiswa memilih lokasi akses pada internet yakni sebanyak $62 \%$. Berikut datanya: 


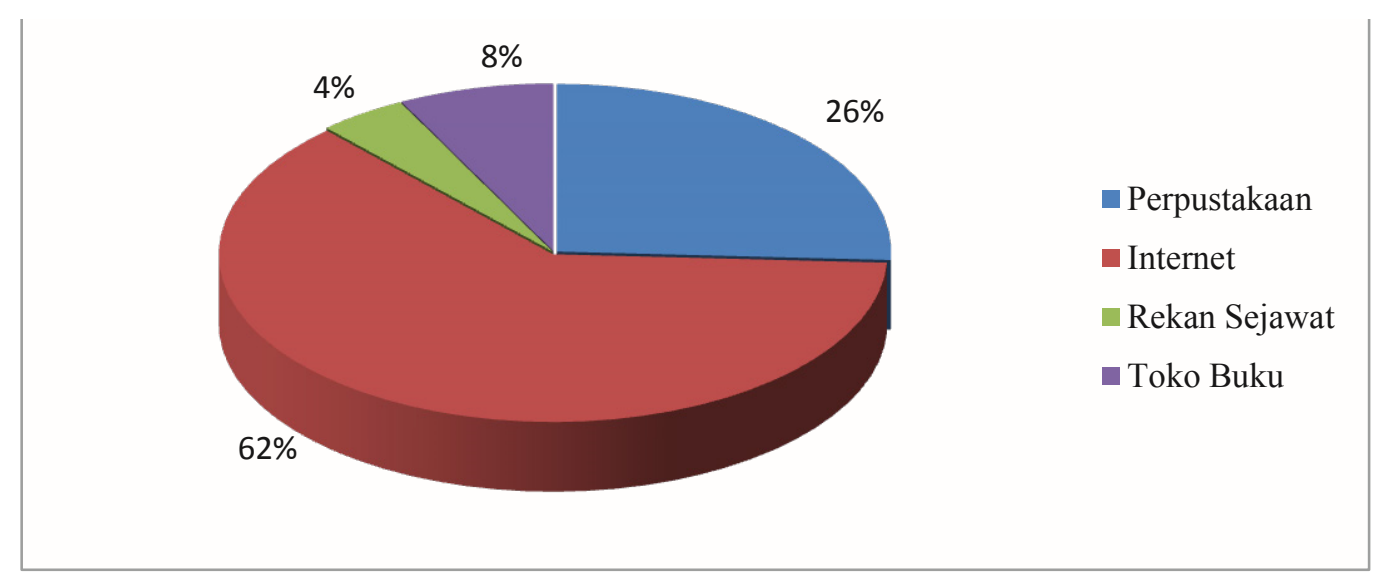

Diagram 2. Lokasi Akses Informasi

Mahasiswamerasabahwadenganmengakses internet, mereka mendapatkan kemudahan dalam mengerjakan tugas yang dibebankan kepada mereka. Hal tersebut juga dipicu karena mereka memiliki alat bantu untuk menelusur di internet yakni dengan menggunakan smartphone pribadi. Hasil penelitian menunjukkan bahwa sebanyak $54,84 \%$ mahasiswa mengakses informasi di internet menggunakan smartphone pribadi.

Pada teori informasi juga menjelaskan mengenai lingkungan sebagai salah satu faktor yang mempengaruhi lokasi akses seseorang ketika akan menelusur informasi. Aspek lingkungan terbagi atas tiga, yakni sosial, budaya, dan ekonomi. Pada penelitian ini, peneliti berusaha menemukan hubungan antara variabel lingkungan melalui pendekatan tiga asepek tersebut dengan varians lokasi akses. Presentase tertinggi untuk aspek sosial adalah sebesar 40,86\% mahasiswa dipengaruhi oleh teman dalam menentukan lokasi akses.

Peneliti menggali informasi lebih jauh mengenai lingkungan sosial yang memiliki presentase cukup besar meski tidak melibihi $50 \%$ mahasiswa yang menjawab bahwa teman berpengaruh terhadap pemilihan lokasi akses. Mereka mengatakan bahwa lebih sering bertanya ke teman terlebih dahulu di mana akan mencari sumber informasi yang dibutuhkan. Kemudian berusaha untuk menelusurnya. Ketika mereka tidak berhasil menemukan setelah mengikuti saran dari teman, mereka berupaya bertanya kepada dosen yang memberi tugas mengenai sumber informasi apa yang seharusnya mereka baca.
Lebih lanjut, jika dilihat dari aspek lingkungan ekonomi maka banyak mahasiswa yang memilih menentukan lokasi akses informasi melalui internet kampus. Beberapa responden memberikan pendapatnya mengenai alasannya memilih internet sebagai pilihan pertama mereka dikarenakan internet kampus bersifat gratis dan dapat digunakan dalam jangka waktu yang panjang. Selain itu, dukungan jaringan internet kampus sudah lancar dan cepat sehingga ketika ada dosen yang memberikan tugas sehabis perkuliahan, mereka dapat langsung menelusur tanpa harus susah lagi berpindah tempat untuk menelusur.

Pengecualian terjadi jika dosen mewajibkan mahasiswa harus menggunakan sumber informasi tercetak atau harus observasi ke instansi/lembaga sehingga mahasiswa tidak mendapat pilihan untuk mengakses selain harus turun langsung ke lapangan. Pada penelitian ini, perpustakaan menjadi pilihan kedua setelah internet karena mereka menyadari bahwa sumber informasi penunjang belajar mereka juga disediakan di perpustakaan universitas namun karena jumlah koleksi yang terbatas, mereka beralih kembali memilih internet yang menjadi pilihan pertama tadi.

Hal tersebut tentu tidak mengherankan, karena jika dilihat dengan pendekatan teori generasi bahwa generasi mereka memang lebih menyukai aktivitas instan, bersentuhan dengan teknologi, dan mencari yang mudah tanpa harus usaha lebih. Meskipun demikian banyaknya pilihan untuk lokasi akses informasi, mahasiswa 
memiliki kecenderungan untuk memilih internet sebagai pilihan akses pertama.

Lokasi akses merupakan faktor penting yang akan mengarahkan seseorang mendapatkan sumber informasi yang dibutuhkannya baik dalam bentuk dokumen maupun nondokumen, tercetak maupun noncetak. Pada penelitian ini, peneliti berusaha menemukan hubungan antara variabel lokasi akses dengan varians sumber informasi. Berikut rincian temuannya:

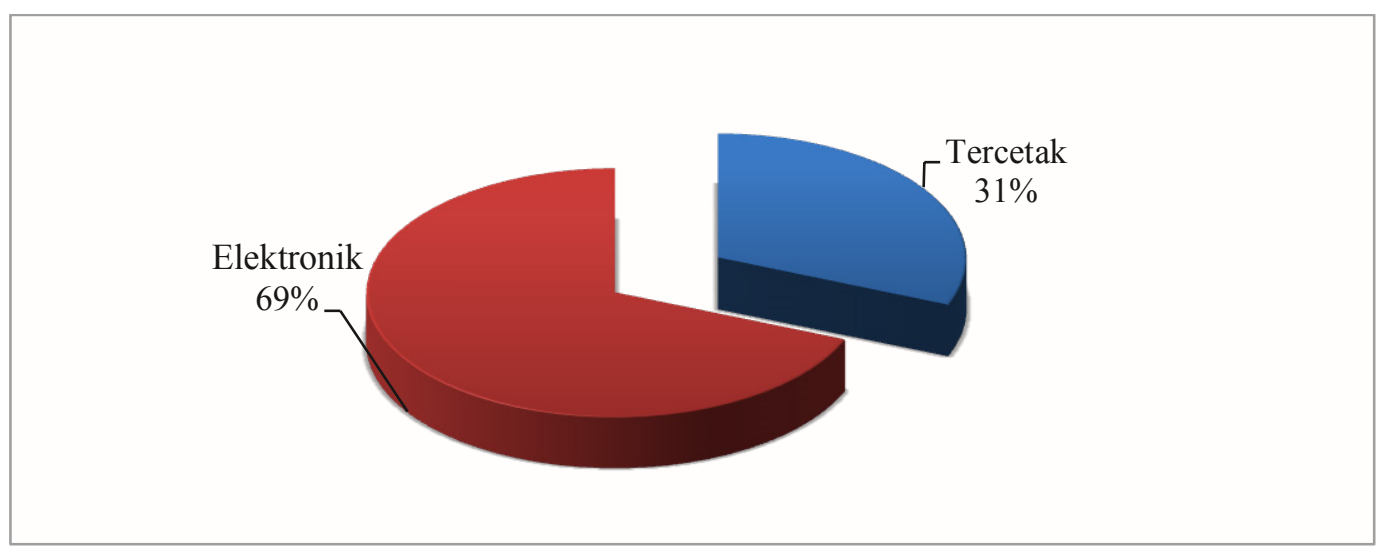

Diagram 3. Jenis Sumber Informasi

Mayoritas mahasiswa menyukai jenis sumber informasi dalam bentuk elektronik sebagai referensi mereka mengerjakan tugas, belajar, maupun menambah pengetahuan. Saat membutuhkan informasi, mahasiswa cenderung mengakses koleksi elektronik baik yang tersebar secara bebas di internet maupun yang ada di virtual akses perpustakaan. Hal tersebut dibuktikan oleh hasil olah data bahwa sebesar $77,42 \%$ mahasiswa menjelaskan bahwa mesin pencari di internet yang menjadi pilihan akses mereka adalah google.

Mereka memahami bahwa internet bukan merupakan satu-satunya tempat untuk mendapatkan sumber informasi yang mereka butuhkan, tetapi ada perpustakaan universitas dan fakultas. Kecenderungan mereka yang lebih memilih internet diimbangi dengan kemampuan mereka dalamberliterasi informasi sehingga tidak terlalu sulit untuk menyeleksi mana informasi yang valid dari sumber yang terpercaya. Bahkan hasil wawancara dengan beberapa mahasiswa, mereka lebih terbiasa menggunakan sumber seperti jurnal dan ETD (electronics theses and dissertations) dari perguruan tinggi lain yang membuka akses layanan pada laman website perpustakaannya. Sebagian besar mahasiswa masih mengakses google untuk mendapatkan rujukan ke sumber primer yang dibutuhkan. Jadi, google hanya difungsikan sebagai penghubung mereka untuk menuju ke sumber yang tepat menurut proses seleksi sumber dan lokasi akses. Tentunya alamat website yang dituju memenuhi syarat sumber informasi yang baik dan ilmiah.

Mahasiswa juga memahami dengan baik bahwa tidak semua sumber informasi yang ada di internet dapat dipertanggungjawabkan isi informasinya. Mereka pula telah mendapatkan teori mengenai penelusuran informasi dan cara menyeleksi serta menggunakan sumber informasi yang terpercaya sebagai salah satu syarat sumber informasi yang layak dipergunakan. Namun pada kenyataannya, meski mereka mengetahui cara akses untuk internet sehat akan tetapi mahasiswa mengalami kesulitan ketika menemukan jurnal internasional dikerenakan terkendala bahasa.

Sebagian besar jurnal online yang ada diinternet disajikan dalam bahasa internasional, yakni bahasa Inggris. Mahasiswa mengalami kendala dalam memahami isi jurnal yang ada dikarenakan kemampuan yang minim terhadap bahasa Inggris. Itu sebabnya mereka masih menggunakan sumber bebas yang disajikan dalam bahasa Indonesia namun tetap 
memperhatikan kredibilitas sumber informasi yang akan mereka gunakan sebagai referensi belajar mereka.

\section{KESIMPULAN}

Adapun kesimpulannya bahwa motivasi mahasiswa mengakses informasi atau melakukan penelusuran informasi disebabkan oleh kebutuhan belajar, mencari jawaban terhadap tugas yang diberikan oleh dosen, dan menambah pengetahuan. Namun dari ketiga motivasi kebutuhan informasi mahasiswa tersebut, presentase terbesar yang mendorong mahasiswa melakukan penelusuran adalah mencari jawaban terhadap tugas yang diberikan oleh dosen sebesar $40,86 \%$. Artinya mahasiswa belum didasari oleh kemauan pribadi untuk meningkatkan kualitas hidupnya dengan menambah wawasan melalui aktivitas menelusur informasi. Dengan kata lain, mereka belum tergolong ke dalam masyarakat informasi. Masyrakat yang sadar terhadap pentingnya informasi bagi kehidupan mereka, baik untuk pengembangan diri maupun untuk menyelesaikan persoalan yang dihadapi.

Hasil analisis dan pembahasan juga memberikan kesimpulan bahwa pola perilaku penelusuran informasi mahasiswa tidak terlalu dipengaruhi oleh lingkungan sosial dan budaya, namun cukup dipengaruhi oleh lingkungan ekonomi. Mereka memiliki kecenderungan untuk mengakses informasi dengan sentuhan sistem dan teknologi. Hal tersebut didukung dengan adanya fasilitas yang mendukung perilaku tersebut. Sebagian besar mahasiswa, yakni $54,84 \%$ mahasiswa melakukan penelusuran informasi menggunakan smartphone pribadi. Fasilitas tersebut juga didukung dengan adanya layanan internet kampus yang dapat diakses sepanjang hari selama mahasiswa berada di area kampus dengan koneksi yang baik. Hal tersebut dibuktikan dengan perolehan data sebesar 67,74 $\%$ mahasiswa memilih melakukan penelusuran informasi dengan internet. Membeli buku dianggap mahal oleh mahasiswa, di samping itu jumlah koleksi yang ada di perpustakaan yang terbatas menjadi alasan mereka memilih akses informasi melalui internet.

Selanjutnya, dari analisis dan pembahasan juga dapat disimpulkan bahwa mayoritas mahasiswa menyukai penelusuran pada sumber informasi yang bersifat elektronik yang disebabkan kemudahan akses dan memiliki biaya yang relatif murah dibandingkan membeli buku dan pergi ke perpustakaan dengan resiko belum tentu mendapatkan buku yang diinginkan karena jumlah koleksi yang terbatas. Hal tersebut dibuktikan dengan perolehan data sebanyak $68,82 \%$ mahasiswa memilih jenis sumber informasi elektronik sebagai sumber informasi yang menjadi referensi kebutuhan informasi mereka. Serta 77,42 \% mereka mengakses google dalam melakukan penelusuran informasi. Adapun sumber informasi tercetak yang sering mereka gunakan ketika mengunjungi perpustakaan didominasi oleh penggunaan koleksi buku yakni sebesar $81,72 \%$. Berdasarkan fakta tersebut dapat ditarik kesimpulan bahwa pola perilaku mahasiswa cenderung memilih internet, mengakses menggunakan gadget pribadi (smartphone), kemudian mengakses sumber informasi elektronik secara bebas melalui mesin pencari (search engine) google guna memenuhi kebutuhan informasinya. Sehingga membentuk pola penelusuran mulai dari analisis kebutuhan informasi (tugas/ menambah wawasan) lingkungan (ekonomi) - lokasi akses (internet/ perpustakaan) - seleksi (sumber informasi relevan) - evaluasi sumber (tercetak/elektronik).

\section{DAFTAR PUSTAKA}

Bawden, David. 2007. Information Seeking and Information Retrieval: the core of the information curriculum? Journal of Education for Library and Information Science, Vol.48(2), pp. 125-138

Ellis, David. 1993. Modelling The InformationSeeking Patterns of Academic researchers: a grounded theory approach. The Library Quarterly, Information, Community, Policy, Vol.63(4), pp. 469-486

Lambert, Joshua D. 2010. The InformationSeeking Habits of Baptist Minister. Journal of Religious and Theological Information, Vol. 9, pp. 1-19

Latan, Hengky dan Imam Ghozali. 2012. Partial Least Squares : konsep, teknik, dan 
aplikasi SmartPLS 2.0 M3 untuk penelitian empiris. Semarang : Badan Penerbit Undip Pendit, Putu Laxman. 2003. Penelitian Ilmu Perpustakaan dan Informasi: suatu pengantar diskusi epistemologi dan metodologi. Jakarta: JIP-FSUI

Savolainen, Reijo. 1995. Everyday Life Information Seeking: approaching information seeking in the context of "way of life". LISR (17), pp.259-294

Setiarso, Bambang. 1997. Penerapan teknologi Informasi dalam Sistem Dokumentasi dan Perpustakaan. Jakarta : Grasindo

Shan-Ju L. Chang and Hsiao-Shan Hung. 2003. An Information Behavior Approach to Knowledge Management: from research to practice. Journal of Education for Library and Information Science, Vol.44(3/4), pp. 208-220

Weiler, Angela. 2004. Information-Seeking Behavior in Generation $Y$ students: motivation, critical thinking, and Learning Theory. The Journal of Academic Librarianship, Vol. 31(1), pp. 46-53
Wilson, T.D. 2006. On User Studies and Information Needs. Journal of Documentation, Vol.62 (6), pp 658-670

Wilson, T.D. 1999. Models in Information Behaviour Research. The Journal of Documentation, Vol.33 (5), pp. 249-270

Yusup, Pawit M. dan Priyo Subekti. 2010. Teori dan Praktik Penelusuran Informasi. Jakarta: Kencana

\section{Sumber Elektronik}

Elita, Funny Mustikasari. 2010. Kebutuhan dan Perilaku Pencarian Informasi. Diakses pada 11 Juni 2016 pada lawan website

https://funnymustikasari.wordpress. com/2010/07/26/perilaku-pencarianinformasi/

Mendoza, Jorge L. (tt). Motivation. Oklahoma : Psychology Department of Oklahoma University. Diakses pada 21 Juni 2016 pada laman website http://www.ou.edu/ faculty/M/Jorge.L.Mendoza-1/Motivation. pdf 